\title{
Coastal Upwelling and Oikopleura Occurrence ("Slub"): A Model and Potential Application to Inshore Fisheries
}

\author{
Christopher T. Taggart ${ }^{1}$ \\ Department of Biology, Dalhousie University, Halifax, N.S. B3H 4J1
}

and Kenneth T. Frank

Department of Fisheries and Oceans, Marine Fish Division, Bedford Institute of Oceanography, P. O. Box 1006, Dartmouth, N.S. B2Y 4A2

Taggart, C. T., and K. T. Frank. 1987. Coastal upwelling and Oikopleura occurrence ("slub"): a model and potential application to inshore fisheries. Can. J. Fish. Aquat. Sci. 44: 1729-1736.

\begin{abstract}
Variations in the occurrence of Oikopleura spp. were strongly linked to the wind field and ensuing water temperatures in an inshore region of eastern Newfoundland during June-August of 1979 and 1981-83. Oikopleura foul inshore fishing gear with their discarded houses ("slub") and fluctuate in abundance from day to day as a function of wind-driven upwelling. Densities of Oikopleura in cold upwelling water during four years ranged between 20 and $800 / \mathrm{m}^{3}$. Oikopleura densities $<1 / \mathrm{m}^{3}$ occurred when upwelling ceased and warmer water occupied the inshore region. A simple model incorporating a daily averaged wind vector, Julian day, and growing degree-day explained $62 \%$ of the daily variation in Oikopleura abundance in 1979. The model yielded density estimates that were significantly $(p<0.05)$ correlated with observed densities in each of the other three years. We provide evidence that net fouling by Oikopleura in the inshore and maximum Atlantic cod (Gadus morhua) catch is coincident and suggest that an annual hindcast index of slub intensity may help determine the impact of slub conditions on the inshore fishery.
\end{abstract}

De juin à août 1979 et 1981-1983, les variations de la fréquence de Oikopleura spp. étaient fortement liées à la vitesse du vent et à la température de l'eau dans une région côtière de l'est de Terre-Neuve. Les cocons abandonnés de Oikopleura encrassent les engins de pêche côtière; I'abondance de cet organisme fluctue d'une journée à l'autre en fonction des remontées d'eaux profondes entraînées par le vent. Dans les eaux froides de remontées profondes, les densités de Oikopleura ont varié de 20 à $800 / \mathrm{m}^{3}$ pendant quatre années. Des densités inférieures à $1 / \mathrm{m}^{3}$ ont été observées quand les remontées d'eaux profondes ont cessé et que des eaux plus chaudes baignaient la région côtière. Un modèle simple portant sur un vecteur moyen quotidien du vent, le jour Julien et le degré-jour de croissance a expliqué $62 \%$ de la variation quotidienne de l'abondance de Oikopleura en 1979. Le modèle a généré des estimations de la densité qui étaient corrélées de façon significative $(p<0,05)$ avec les densités observées au cours des trois autres années. Nous présentons des preuves à l'effet que la salissure des filets côtiers par Oikopleura et les prises maximum de morue de I'Atlantique (Gadus morhua) coïncident; de plus, nous formulons l'hypothèse qu'un indice annuel de l'intensité des salissures pourrait servir à déterminer l'incidence de celles-ci sur la pêche côtière.

Received December 12, 1986

Accepted June 8, 1987

(J9048)
Reçu le 12 décembre 1986 Accepté le 8 juin 1987
$\mathbf{T}$

he mucous houses of Oikopleura spp. (Tunicata: Appendicularia) are responsible for the "slime" or "slub" (as it is termed in Nova Scotia and Newfoundland, respectively) that fouls the trap and gill nets of inshore fishermen in the Northwest Atlantic region (Buggeln 1978, 1980; Mahoney and Buggeln 1983; Deibel 1987). The relatively large (6-40 mm) (Alldredge 1976; Deibel 1978) houses of Oikopleura are produced at a maximum rate of between 6 and 8 /day by an individual larvacean (Lohmann 1909; Barnes 1974; Hamner et al. 1975) and readily accumulate on fishing nets set for Atlantic cod (Gadus morhua) and Atlantic salmon (Salmo salar) (Buggeln 1980; Mahoney and Buggeln 1983; Deibel 1987). It is supposed that Oikopleura fouling reduces the efficiency of nets.

\footnotetext{
'Mailing address: Bedford Institute of Oceanography, P.O. Box 1006, Dartmouth, N.S. B2Y 4A2.
}

The houses and associated particulates (e.g. phytoplankton, microzooplankton, fecal pellets, detritus, etc.) (Alldredge 1976) make nets more visible and they are presumably avoided by fish (Diebel 1987). Nets must be frequently hauled for cleaning, resulting in reduced fishing effort and catch (Mahoney and Buggeln 1983; Lear et al. 1986). Net fouling by Oikopleura is a serious problem: it has drawn considerable media attention (Buggeln 1980; Lear et al. 1986), methods of cleaning and treating nets have been systematically investigated (Buggeln 1978; Deibel 1987), and a recent report on the factors affecting the inshore cod fishery highlighted Oikopleura as a contributing factor to reduced fishing efficiency, effort, and catch (Lear et al. 1986).

Fishermen are aware of the conditions leading to slub and agree that it is most apparent under wind conditions coincident with the appearance of cold, clear water (Buggeln 1978, 1980). 
Several authors attest the observations made by fishermen and suggest that the occurrence of slub is a function of variations in the wind, current, and tide which result in cold water masses, laden with Oikopleura, invading the inshore (Buggeln 1978; Lear et al. 1986). In support of this explanation the two most common species of Oikopleura in the Northwest Atlantic ( $O$. vanhoeffeni and $O$. labradoriensis) are cold-water inhabitants (Udvardy 1954; Bückmann 1970), their houses are extremely adhesive to fishing net material (Mahoney and Buggeln 1983), and $O$. vanhoeffeni is one of the largest species (Diebel et al. 1985).

Recent work by Frank and Leggett $(1981,1982)$ and Taggart and Leggett (1987) demonstrated that the water mass and plankton community dynamics in the inshore zone of eastern Newfoundland are intimately tied to variations in the wind field on the scale of 2-6d, a result consistent with Templeman's (1966) wind-driven water mass exchange hypothesis. The predominant effect of wind forcing in this region is the periodic upwelling of cold subthermocline water in the inshore and an accompanying change in composition of the plankton community. As $O$. vanhoeffeni and $O$. labradoriensis are cold-water inhabitants, and as slub is a periodic phenomenon apparently related to meteorological and water mass dynamics, we hypothesized that oscillations in the occurrence of Oikopleura in the inshore would be a predictable function of wind.

In this paper we examine the relationship between variation in the occurrence of Oikopleura in the inshore waters of eastern Newfoundland and variation in meteorological and hydrographic data. A simple model is derived and tested using three independent data sets. We explore the potential of the model for addressing problems in the inshore fishery.

\section{Methods}

\section{Data Sources}

Oikopleura spp. were collected during the summers of 1979 and 1981-83 in the inshore region of Bryants Cove, Newfoundland $\left(45^{\circ} 40.5^{\prime} \mathrm{N}, 53^{\circ} 11.0^{\prime} \mathrm{W}\right)$. In 1979 , sample volumes of $\sim 2 \mathrm{~m}^{3}$ each were collected at a depth of $1 \mathrm{~m}$ almost daily from 12 June through 26 July at three sites immediately adjacent to the beach at the head of the cove with a $153-\mu$ m-mesh net mounted on a Plexiglas sled (Frank and Leggett 1981). During $1981-83$ an 80- $\mu \mathrm{m}$-mesh net and a high-volume pump (Taggart and Leggett 1984) were used to collect Oikopleura. Samples of $1-2 \mathrm{~m}^{3}$ volume were taken from late June to early August (every $0.3-2 \mathrm{~d})$ at as few as 7 and as many as 43 sites throughout the cove (Taggart and Leggett 1987). Sampling depth ranged from 0 to $9 \mathrm{~m}$. All of the samples were preserved in $4 \%$ formalinseawater buffered with sodium borate. Oikopleura were enumerated from all samples unless the number appeared $>100$ in which case subsamples were taken using the Huntsman Marine Laboratory "beaker" technique (Van Guelpen et al. 1982), and the total numbers were estimated.

Daily measurements of water temperature were taken in 1979 in the subtidal zone adjacent to the beach at Bryants Cove using a YSI thermistor probe. The only temperature records available during 1981 were those provided by $S$. Akenhead (Department of Fisheries and Oceans, St. John's, Nfld.) from a Ryan thermograph recording at 4-h intervals and located at $10 \mathrm{~m}$ depth in Harbour Grace, an embayment immediately adjacent $(1.6 \mathrm{~km})$ to Bryants Cove. We considered the data from Harbour Grace representative, as Leggett et al. (1984) have shown that at much larger scales, temperature variations along the entire east coast of Newfoundland are similar and synchronous. Temperature records for 1982-83 were obtained at 10-min intervals from an Aanderra RCM4 current meter moored at a depth of $4.5 \mathrm{~m}$ in the cove from June to August. Temperature data from 1982-83 were smoothed to hourly values using a standard narrow-band filter (Godin 1972) to remove high-frequency variations $(<1 \mathrm{~h}$ ) (see Taggart and Leggett 1987). Daily temperature records for 1979 and thermograph data for 1981 were not smoothed.

Hourly wind speed and direction and growing degree-day values $\left(5^{\circ} \mathrm{C}\right.$ baseline) measured at St. John's airport (located $33 \mathrm{~km}$ east of Bryants Cove) were obtained from monthly meteorological summaries (Environment Canada, Atmospheric Environment Service (AES)). Wind directions were rotated $180^{\circ}$ to downwind and speed and direction were decomposed into offshore $\left(U_{w}\right)$ and longshore $\left(V_{w}\right)$ vectors resolved around $54^{\circ}$ (the major axis offshore direction at Bryants Cove). These data were smoothed with a single pass of an hour-centred normally weighted 12-point moving average (Taggart and Leggett 1987).

\section{Analysis}

Multivariate linear regression was used to examine the relationship between Oikopleura abundance and a number of meteorological and hydrological variables. Oikopleura abundance was expressed as a daily geometric average $\left(\log _{e}\left(\right.\right.$ no. $\left./ \mathrm{m}^{3}\right)$ $+1)$. This transformation was chosen to improve the skewed distribution of the data caused by the disproportionately large number of zero and near-zero abundance estimates. The independent variables included the water temperature at the time of sampling (or an average value if more than one measurement was made in one day), $U_{w}$ averaged over $3,6,12$, and $24 \mathrm{~h}$ immediately prior to sampling, the daily growing degree-day estimate, the daily cummulative growing degree-day estimate, and the Julian day. These variables were chosen a priori because (1) there was evidence that temperature and wind influence Oikopleura abundance (Udvardy 1954; Bückmann 1970; Buggeln 1978; Lear et al. 1986), (2) Julian day had the potential to account for the generally declining seasonal trends in Oikopleura abundance which have been reported in the literature (Mahoney and Buggeln 1983) and were apparent in our data, and (3) growing degree-day provides a surrogate measure of potential heat input to the water column and has been successfully used in modelling event timing and biological production in other aquatic systems (e.g. Burgner 1980; Colby and Nepszy 1981; Leggett et al. 1984).

Multivariate analysis was used to identify those variables which consistently explained the most variation in the Oikopleura abundance observed within and among years. Our quantitative selection criteria were the regression statistics $r^{2}$, Mallows $C p$ (Hocking 1976), and $F$-values. Once selected, the variables were used to model only the 1979 data. The 1979 data series was chosen to provide the model parameters because (1) it was a relatively long series, (2) it began earlier in the season than any of the other years, and (3) it displayed the greatest amount of variation in Oikopleura abundance. The resulting model was then tested independently on the 1981-83 data series. The goodness of fit between the observed values and those produced by the model for each year was assessed using parametric (Pearson) and rank (Spearman) correlation statistics. 


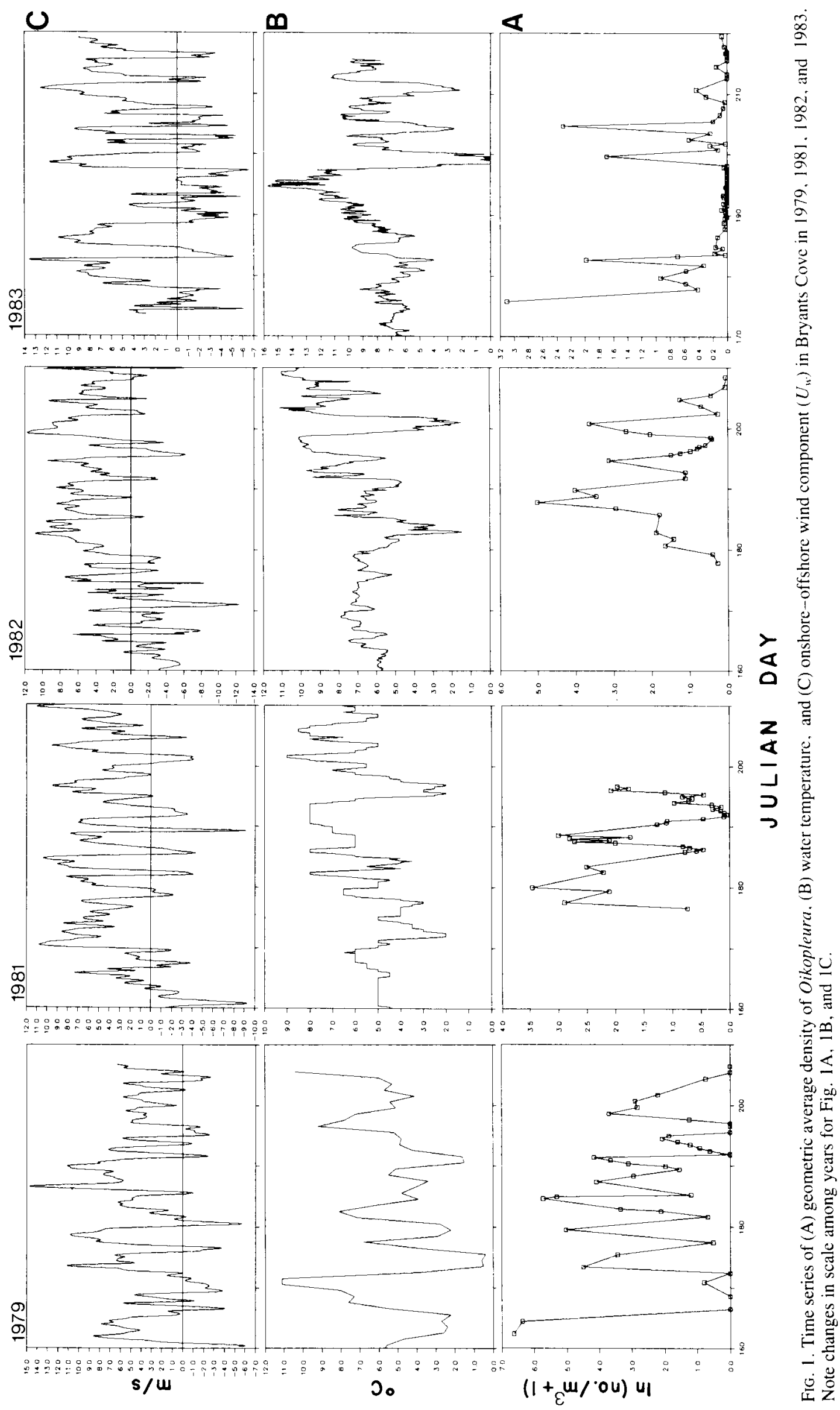


TABLE 1. Pearson correlation coefficients between the geometric average of Oikopleura density, water temperature, and the 24-h average of the $U$-component of wind $\left(U_{\mathrm{w} \cdot 24}\right)$. Significance of correlation and sample size for each year and all years combined is provided.

\begin{tabular}{lccccc}
\hline Cross variables & 1979 & 1981 & 1982 & 1983 & All years \\
\hline$U_{w 24}$ & -0.66 & -0.56 & -0.70 & -0.61 & -0.61 \\
Temperature & 0.0001 & 0.026 & 0.0001 & 0.0001 & 0.0001 \\
& 32 & 16 & 25 & 39 & 112 \\
$U_{w 24}$ & 0.74 & 0.39 & 0.61 & 0.30 & 0.49 \\
Oikopleura & 0.0001 & 0.132 & 0.0012 & 0.05 & 0.0001 \\
& 32 & 16 & 25 & 41 & 114 \\
Temperature & -0.61 & -0.39 & -0.59 & -0.43 & -0.56 \\
Oikopleura & 0.0002 & 0.135 & 0.002 & 0.007 & 0.0001 \\
& 32 & 16 & 25 & 39 & 112 \\
\hline
\end{tabular}

\section{Results}

Abundance estimates of Oikopleura in Bryants Cove exhibited extreme inter- and intra-annual variation (Fig. 1A). Maximum densities of Oikopleura during the four summers ranged between 20 and $800 / \mathrm{m}^{3}$. Minimum densities were frequently $<1 / \mathrm{m}^{3}$. Within-year variation in Oikopleura abundance appeared on inspection to be inversely correlated with water temperature (Fig. 1B) and positively correlated with $U_{w^{\prime}}$ (Fig. 1C). Periods of prolonged offshore wind (positive values of $U_{k}$ ) and sharply declining temperature, particularly in 1979 and 1981, were coincident with increased densities of Oikopleura. In contrast, periods of relatively weak offshore winds or prolonged onshore winds (negative values of $U_{w}$ ) resulted in increased temperature and decreased Oikopleura abundance. This was particularly evident between days 189 and 198,1983 (8-17 July), when water temperature increased almost monotonically from 7 to $\sim 16^{\circ} \mathrm{C}$ and there were virtually no Oikoleura in the water column (Fig. 1A).

The above observations are supported by significant inverse correlations between $U_{w}$ averaged over $24 \mathrm{~h}\left(U_{\mathrm{w} \cdot 24}\right)$ and temperature in each year and for all years combined (Table 1). This result is consistent with the reciprocal relationship between wind stress and water temperature derived from spectral analysis techniques (Taggart and Leggett 1987). Oikopleura density was significantly and positively correlated with $U_{w 24}$ in three of the four years and for all years combined. Oikopleura was negatively correlated with temperature, a result that is consistent with reports from previous studies (see the introduction). $U_{w 24}$ exhibited the strongest correlation with both temperature and Oikopleura abundance among the four averages of $U_{\mathrm{w}}$ analysed $(3,6,12$, and $24 \mathrm{~h})$.

Exploratory multivariate regression analysis revealed that $U_{w 24}$, Julian day, and growing degree-day (all three were normally distributed and were readily available from monthly meteorological summaries) consistently provided the greatest amount of explained variation in the occurrence of Oikopleura in Bryants Cove both within and among years. $U_{n \cdot 24}$ alone explained the greatest amount of variation in four out of five analyses (1979, 1981, 1982, 1983, and all years combined). Temperature did not generally make a significant contribution to the explained variance due to its strong correlation with $U_{w 24}$ (Table 1). Julian day and growing degree-day each provided significant contributions to the explained variance in three out of the five analyses.

Fitting the three variables to the 1979 data set yielded the following model which explained $62 \%(p<0.0001)$ of the total variation in Oikopleura abundance (Fig. 2A).

(1) Oikopleura $=0.421 U_{w 24}+0.067 \mathrm{GDD}-0.041 \mathrm{JD}+7.775$

where Oikopleura density was expressed as $\log _{e}\left(\right.$ no. $\left./ \mathrm{m}^{3}+1\right)$, GDD was the daily growing degree-day, and JD was the Julian day. The model was judged statistically sound because the independent variables and their parameter estimates were not correlated $(\alpha=0.05)$, colinearity among the independent variables was not evident (diagnostic procedure of Belsley et al. 1980), and the error estimates were not autocorrelated (DurbinWatson two-tailed $d$ statistic, $\alpha=0.05$, Draper and Smith 1980).

When the model parameters were applied to the 1981-83 data the output reproduced the observed oscillations of Oikopleura in each year (Fig. 2B, 2C, 2D). Variations in amplitude were also reflected by the model for all years except 1983 (Fig. 2D). The parametric and nonparametric correlation coefficients between the observed and modelled Oikopleura densities were significant in all cases $(p \leq 0.05)$, although not surprisingly weakest in 1983 (Table 2). The overall significance of fit of the model in the three independent tests using the combined probability test (Sokal and Rohlf 1969) was $p<0.00004$.

\section{Discussion}

\section{The Model}

The simple empirical model (eq. 1) not only reproduced major oscillations in the occurrence of Oikopleura in Bryants Cove, it also provided statistically significant estimates of Oikopleura density in all years tested. We believe that this resulted mainly because the wind field is an excellent predictor of the physical (e.g. temperature, salinity, currents) and biological (e.g. capelin larvae, micro- and macro-zooplankton, gelatinous zooplankton, etc.) characteristics of water masses in the inshore (Taggart 1986; Taggart and Leggett 1987; Frank and Leggett 1981, 1982) and because Oikopleura is an indicator of water mass type (Udvardy 1954; Bückmann 1970). The fact that $U_{w 24}$ was the dominant variable confirms the observation by fishermen that slub conditions are most severe during periods of upwelling favourable winds, no matter what geographic location is considered (Buggeln 1978, 1980). Nevertheless, it is important to recognize that the wind variable $\left(U_{w 24}\right)$ in the model is site specific. It is doubtful that the offshore orientation used 

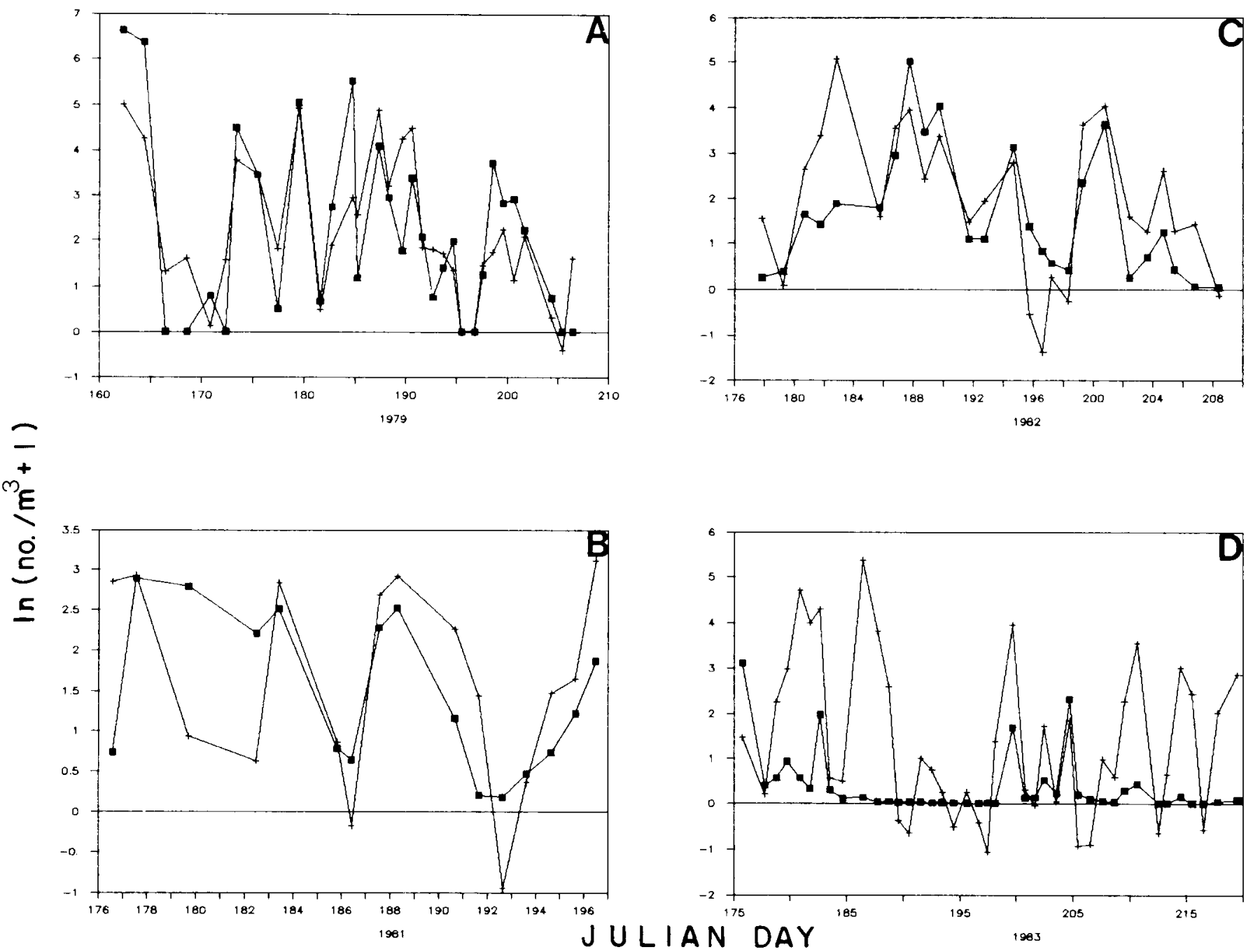

FIG. 2. Time series of observed ( $\square$ ) and modelled $(+)$ variations in the inshore geometric average density of Oikopleura in Bryants Cove in (A) 1979, (B) 1981, (C) 1982, and (D) 1983.

TABLE 2. Parametric and nonparametric correlation coefficients for the observed and modelled Oikopleura density estimates. Sample size $(n)$ and significance level (parentheses) are provided for each year.

\begin{tabular}{cccc}
\hline \hline Year & $n$ & Pearson & Spearman \\
\hline 1979 & 32 & 0.786 & 0.786 \\
& & $(0.0001)$ & $(0.01)$ \\
1981 & 16 & 0.555 & 0.605 \\
& & $(0.026)$ & $(0.02)$ \\
1982 & 25 & 0.680 & 0.744 \\
& & $(0.0002)$ & $(0.01)$ \\
1983 & 41 & 0.339 & 0.492 \\
& & $(0.030)$ & $(0.01)$ \\
\hline
\end{tabular}

to calculate $U_{w}$ at our location is universally applicable when it is generally understood that lar-er scale coastal upwelling is driven by longshore winds (e.g. Yao 1986). If the model is used for other locations the wind vectors must be resolved according to the downwind direction of winds that induce upwelling.

The model is currently restricted in application to the June-August period and has relatively poor predictive power in the first part of the season. This was particularly evident early in 1981 when the observed densities of Oikopleura were considerably higher than the modelled densities (Fig. 2B). During early summer the entire water column is cold $\left(<5^{\circ} \mathrm{C}\right)$ and therefore ideal for Oikopleura to thrive, but their abundance is less predictable from the ambient wind condition. We expected that either water temperature or growing degree-days would account for this variation, but the data are sparse during the early June period and thus not adequately accounted for in the model.

Although the model reflected the oscillatory nature of the observed Oikopleura density in all years, amplitude was not well accounted for, particularly in 1983 (Fig. 2D). Failure of the model to account for extreme variations in amplitude is possibly due to the absence in the model of any biological variates such as phytoplankton production or standing crop (food for Oikopleura) and predator abundance and their interaction with Oikopleura population growth rates, fecundity, and generation time. These variables would obviously account for the intrinsic population dynamics of Oikopleura that are independent of water mass dynamics. However, our intent was not to model the population dynamics of Oikopleura absolutely, but simply to account for the relative abundance of Oikopleura (and therefore slub) in the inshore by examining the water mass dynamics. Although such biological variates may improve the model, they 
TABLE 3. Temperature ranges $\left({ }^{\circ} \mathrm{C}\right)$ coincident with high cod catch in various seasons and locations reported in the literature.

\begin{tabular}{|c|c|c|c|}
\hline $\begin{array}{c}\text { Temperature } \\
\left({ }^{\circ} \mathrm{C}\right)\end{array}$ & Season & Location & Source \\
\hline $0-6$ & Feb.-May & $\begin{array}{c}\text { Southern Grand Bank } \\
\text { Div. 3-O, 3N }\end{array}$ & Thompson 1943 \\
\hline $3-5$ & May-June & Spitzbergen & Lee 1952 \\
\hline $3.5-4$ & Aug.-Nov. & (Bear Island) & \\
\hline$-1-4$ & Summer & $\begin{array}{l}\text { Grand Bank } \\
\text { Div. 3L }\end{array}$ & Rodriguez and Rojo 1955 \\
\hline $0-5$ & Summer & $\begin{array}{l}\text { Inshore } \\
\text { Div, } 2 \mathrm{~J}, 3 \mathrm{KL}\end{array}$ & Templeman and Fleming 1956 \\
\hline$-1-4$ & May-June & $\begin{array}{l}\text { Southern Gulf of } \\
\text { St. Lawrence and } \\
\text { Laurentian Channel }\end{array}$ & Martin 1961 \\
\hline $0-6$ & Summer & Gulf of St. Lawrence & Jean 1964 \\
\hline $1-8$ & Summer & Scotian Banks & \\
\hline $2.5-3.1$ & April-May & Hamilton Bank & Templeman and May 1965 \\
\hline$-0.8-8.7$ & June & Div. 2J & \\
\hline$-0.5-5$ & Summer & Barents Sea & Woodhead and Woodhead 1965 \\
\hline $2-4$ & All & $\begin{array}{l}\text { Scotian Shelf } \\
\text { Div. } 4 \mathrm{Vn}, 4 \mathrm{Vs}\end{array}$ & Scott 1982 \\
\hline$-0.9-4$ & June & $\begin{array}{l}\text { Inshore and offshore } \\
\text { Div. 3L }\end{array}$ & Lear et al. 1986 \\
\hline Median $=2.9$ & & & \\
\hline
\end{tabular}

are generally unavailable and would effectively reduce the utility of the model to other workers if such variables were incorporated. Autecological studies of Oikopleura species have shown that the clearance rates of $O$. vanhoeffeni are high $(<15 \mathrm{~L} / \mathrm{d})$, and the species could have a major impact on phytoplankton populations (Diebel and Turner 1985), but how Oikopleura populations respond (if at all) to phytoplankton production and predation pressure is unknown.

One variable likely to provide the greatest improvement to the model is the generation time of the cold-water Oikopleura species, but it is unknown. Generation times have been measured for the warmer-water species $O$. dioica (preferred temperature range $7-18^{\circ} \mathrm{C}$ ) and were estimated to fall between 24 and $144 \mathrm{~d}$ (Paffenhöfer 1975; Wyatt 1973). It is probable that the generation times for the cold-water species are greater than their warm-water congeners, and the limited data available indicate that there may ony be one or possibly two generations each year (D. Diebel, Mar. Sci. Res. Inst., Memorial University of Newfoundland, St. John's, Nfld., pers. comm.). If there are only one or two generations each year, then adding this information to a model that makes predictions on the scale of days would probably yield limited improvement.

We suggest that the relatively low predictive power of the model in 1983 may be the result of increased surface water temperature in 1983 that either limited the development of normally large populations of Oikopleura or limited their appearance inshore due to an increased depth of the surface layer which would require stronger than average and more persistent offshore winds to induce upwelling. It is widely recognized that 1983 was an anomalous year throughout the Northwest Atlantic with record high sea-surface temperatures (Trites and Drinkwater 1985). A summary of the water temperature data from our study (see below) is consistent with the suggestion that warm water temperatures limited the occurrence of Oikopleura in 1983 relative to the other years:

\begin{tabular}{ccccccc} 
& \multicolumn{3}{c}{ Temperature $\left({ }^{\circ} \mathrm{C}\right)$} & & & $\begin{array}{c}\text { Average } \\
\text { Oikopleura } \\
\text { Yensity }\end{array}$ \\
\cline { 2 - 6 } & Minimum & Maximum & Mean & $\mathrm{CV}$ & $n$ & \\
$\left(\mathrm{no} . / \mathrm{m}^{3}\right)$ \\
1979 & 0.4 & 11.1 & 5.05 & 51.7 & 47 & 8.78 \\
1981 & 0.0 & 13.0 & 6.98 & 44.7 & 528 & 4.25 \\
1982 & 1.48 & 11.55 & 6.96 & 28.4 & 1439 & 4.98 \\
1983 & -0.97 & 15.70 & 7.40 & 36.9 & 1295 & 1.44
\end{tabular}

It is important to note that in 1979 the average water temperature in Bryants Cove was the lowest among the four years and coincided with the greatest average abundance of Oikopleura. Also, intermediate temperatures in 1981 and 1982 corresponded with intermediate Oikopleura densities. However, while the surface temperatures were anomalously high in 1983, the subsurface temperatures were anomalously low (Lear et al. 1986). The minimum temperature measured in Bryants Cove in 1983 (above) is in agreement with the findings of Lear et al. (1986) and suggests the alternative possibility that Oikopleura production was limited in 1983 by colder than average subsurface temperatures.

Implications to the Inshore Fishery

The results of our analysis suggest that to avoid slub conditions and the fouling of nets in the inshore, fishermen could pursue several options: (1) avoid setting nets below the seasonal thermocline; (2) avoid locations where upwelling conditions and cold temperatures prevail; (3) retrieve nets from locations when upwelling favourable winds prevail at the location; or (4) clean nets after a period of upwelling favourable winds. However, with the exception of (4), such actions may reduce the catch.

Cod catches in the Northwest Atlantic and elsewhere are generally greatest at a median temperature of $2.9^{\circ} \mathrm{C}$ (range -1 to 8; Table 3) which overlaps the range associated with the high 


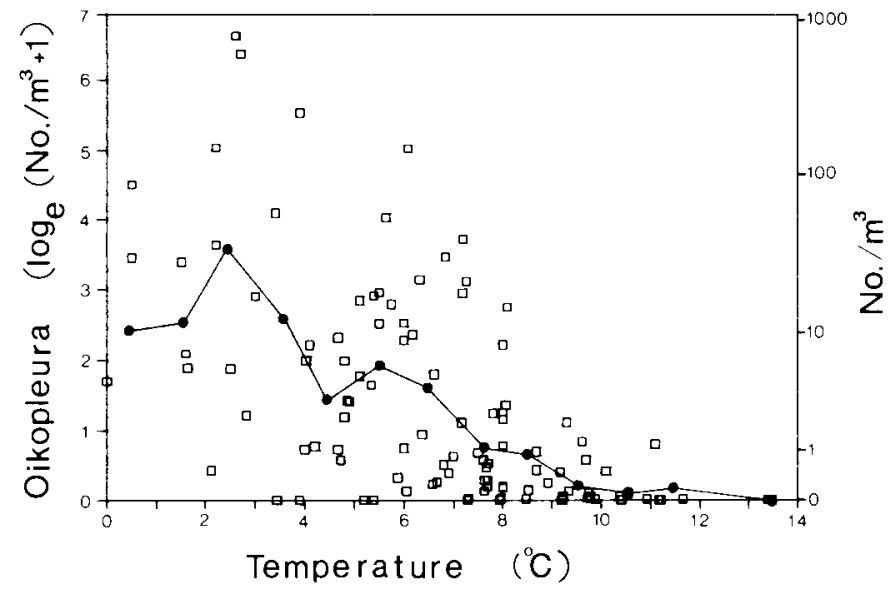

FIG. 3. Scattergram of the relationship between temperature and Oikopleura density for the years 1979 and 1981-83 combined in Bryants Cove. The average densities of Oikopleura for each $1^{\circ}$ step in temperature are joined with a solid line.

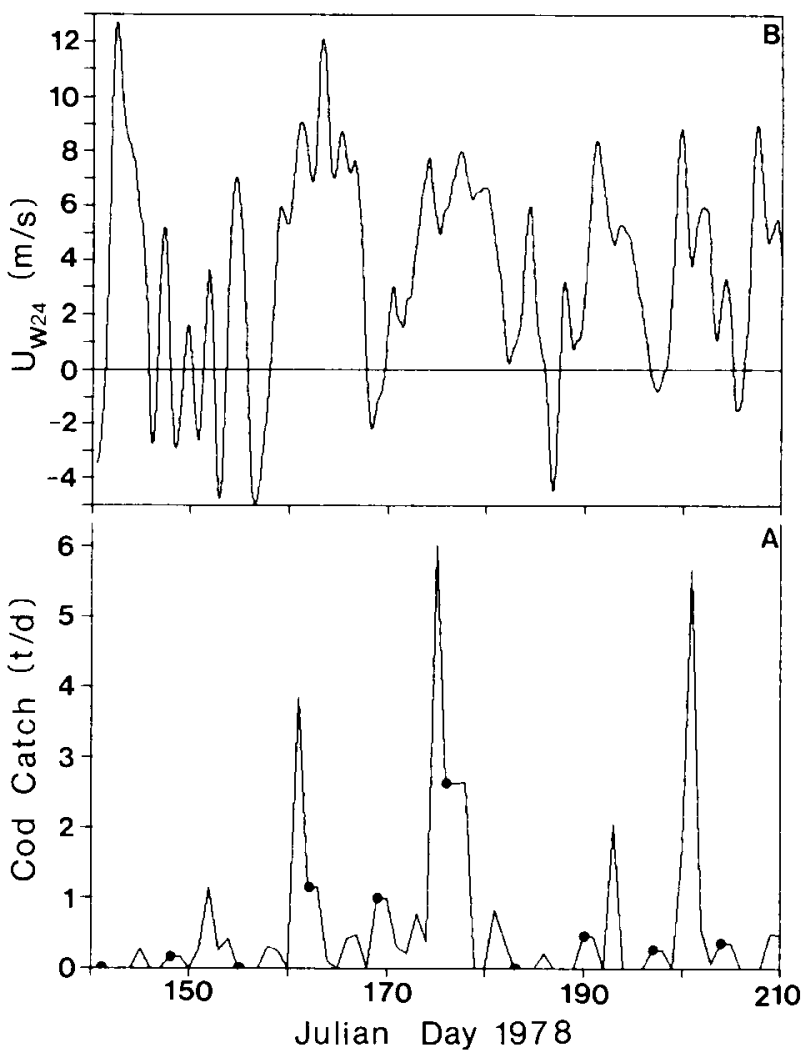

FIG. 4. Time series of (A) daily inshore cod catch and (B) $U_{n \cdot 24}$ in 1978 at Bryants Cove. No fish were landed on Sundays ( ) and therefore, the catch recorded on Monday was divided equally between the two days.

densities of Oikopleura (Fig. 3). This observation provides support for the suggestion that cod and Oikopleura co-occur in the inshore, particularly under conditions of wind-driven upwelling. We qualitatively evaluated this suggestion by examining the relationship between the daily cod catch from an inshore trap in Bryants Cove in 1978 and $U_{\text {w.24 }}$. Cod catch (tonnes per trap per day) was taken from the 1978 landing records provided to us by Mr. W. Parsons (resident fisherman of Bryants Cove).
The largest catches of cod recorded in 1978 (Fig. 4A) were associated with the onset of prolonged periods of offshore (upwelling favourable) winds (Fig. 4B), although there are inconsistencies at the beginning and at the end of the series. Nevertheless, the pattern is very similar to those shown for the abundance of Oikopleura relative to offshore winds (Fig. 1). These results support the suggestion that wind conditions associated with high catches of cod are coincident with conditions favourable to high Oikopleura density and lend credence to reports that fishermen catch fish near fouled gear when using other gear such as jiggers or trawls (Diebel 1987).

Fishing nets are not fouled immediately at the onset of upwelling conditions because slub is a cumulative phenomenon, i.e. a function of the duration of upwelling and the local Oikopleura density. This led us to hypothesize that catch would be highest near the start of an upwelling period and lower near the end of the same period due to a decrease in trap efficiency caused by net fouling. The hypothesis cannot be adequately tested with the data available, but we point out that cod catch did not remain high during prolonged offshore winds (Fig. 4) as did the abundance of Oikopleura (Fig. 1). Alternatively, catch may be reduced during persistent upwelling because of continuously declining temperature. The data available are not suitable for the rejection of either hypothesis.

The apparent relationship between wind and cod catch (Fig. 4) is not new. Jeffers (1931) reported that "The opinion is well-nigh universal that winds are of particular importance in determining the movements of cod." Templeman (1966) suggested that cod catch in the inshore trap fishery was a function of temperature preference of cod, trap position with respect to depth, thermal structure of the water column, and wind condition. This view was echoed by Lear et al. (undated). ${ }^{2}$ Simply restated, Templeman (1966) recommended that nets be set at a depth which intercepts the seasonal thermocline, the zone which spans the cod temperature preference. Buggeln (1978) suggested that traps are inefficient during slub conditions because the water is too cold for cod and not because of fouling. The evidence we have presented does not support Buggeln's suggestion in general, although during periods of persistent upwelling (say $>2 \mathrm{~d}$ ) the interpretation may be correct. Nevertheless, if fouled nets are used when ideal conditions for cod exist, it is very likely that catch will be relatively poor. This implies that to be most successful, fishermen must be wary of the water mass dynamics and fish at depths and locations that allow for a frequent interception of the seasonal thermocline, thus increasing the probability of greater catch and decreasing the probability of net fouling.

Our model could be used to generate an historical time series of slub conditions for each year (a computer program for calculating $U_{w}$ and generating the slub time series is available on request from the authors). An index of the severity of slub for each year could be provided by the integration of the time series, similar to the integrated wind index described by Taggart and Leggett (1987). Tentative support for such an approach is found in a comparison of the "slub years" in Nova Scotia documented by Buggeln (1980) with the annual sea-surface temperature (SST) anomalies for the 1951-81 base period at St. Andrews and Boothbay Harbour (Trites and Drinkwater 1985). Of the six

\footnotetext{
${ }^{2}$ W. H. Lear, C. A. Bishop, and P. R. Hood. Undated. Trap cod. Some facts about unpredictable catches and small fish. Communications Division, Department of Fisheries and Oceans, P.O. Box 5667, St. John's, Nfld. A1C 5X1. 16 p.
} 
slub years considered, 1966, 1967, 1972, and 1980 had anomalously low SSTs at both geographic locations. Near average SSTs existed at both sites during 1970 and 1979 . We further suggest that the index can be compared with the inshore catch statistics for both cod and salmon, and in this manner the relationship between slub and catch could be quantified relative to other factors (e.g. temperature, prey availability, stock size, effort, etc.).

\section{Acknowledgments}

We are grateful to W. C. Leggett and for grants made to him from the Natural Sciences and Engineering Research Council of Canada (NSERC), J. Carscadden and the Department of Fisheries and Oceans, and J-Y Anctil and Group interuniversitaire de reserche océanographiques du Québec for financial and logistic support. C.T.T. was supported by an NSERC postdoctoral fellowship. N. Chalouhi, K. Talion, K. W. Frank, J-C. Dequise, G. Maillet, C. Gravel, and G. Kerhuel provided expertise in the field and laboratory. K. Drinkwater kindly provided advice during the development of the model. S. Kerr, S. Campana, I. McLaren, and two anonymous reviewers provided valuable criticisms of an earlier manuscript. S. Akenhead (Department of Fisheries and Oceans) provided thermograph data for 1981 and Warren Parsons kindly provided his trap landing slips. The residents of Bryants Cove gave us valuable assistance on numerous occasions.

\section{References}

Alldredge, A. L. 1976. Discarded appendicularian houses as sources of food, surface habitats, and particulate organic matter in planktonic environments. Limnol. Oceanogr. 21: 14-23.

Barnes, R. D. 1974. Invertebrate zoology. W. B. Saunders Co.. Toronto, Ont $870 \mathrm{p}$.

Belsley, D. A., E. Kuh, And R. E. Weisch. 1980. Regression diagnostics. John Wiley \& Sons, New York, NY. 292 p.

BückmanN, A. 1970. Die Verbreitung der Kalwasser-und der Warmwasserfauna der Appendicularien im nördlichen Nordatlantischen Ozean im Spätwinter und Spätsommer 1958. Mar. Biol. 5: 35-56.

Buggein, R. G. 1978. Report into "slub". Principal report to Newfoundland and Labrador Department of Fisheries, Development Branch. Part 1, 26 p. Part II, $11 \mathrm{p}$.

1980. The correlation of "slub" on fishing nets with the zooplankton species, Oikopleura vanhoeffeni, in coastal Newfoundland. Final report to Newfoundland and Labrador Department of Fisheries, Development Branch. $10 \mathrm{p}$

Burgner, R. L. 1980. Some features of ocan migration and timing of Pacific salmon, p. 153-164 In W. J. McNeil and D. C. Himsworth [ed.] Salmonid ecosystems of the North Pacific. Oregon State University Press, Corvallis, OR

COLBY, P. J., AND S. J. NEPSZY. 1981. Variations among stocks of walleye (Stizostedion vitreum vitreum): management implications. Can. J. Fish. Aquat. Sci. 38: 1814-1831.

Deibel, D. 1987. Slub: science looks at fishermen's torment. Fo'c'sle 6(2):6-11. Communications Division, Department of Fisheries and Oceans, P.O. Box 5667, St. John's, Nfld. AlC 5 X1.

Deibel, D., M.-L. Dickson, and C. V. L. Powell. 1985. Ultrastructure of the mucous feeding filter of the house of the appendicularian Oikopleura vanhoeffeni. Mar. Ecol. Prog. Ser. 27: 79-86.

Deibel, D., AND J. T. Turner. 1985. Zooplankton feeding ecology: contents of fecal pellets of the appendicularian Oikopleura vanhoeffeni. Mar. Ecol. Prog. Ser. 27: 67-78.

DraPER, N. R., AND H. SMITH. 1980. Applied regression analysis. John Wiley \& Sons, New York, NY. 709 p.

Frank K. T., AND W. C. LegGetT. 1981. Wind regulation of emergence times and early larval survival in capelin (Mallotus villosus). Can.J. Fish. Aquat. Sci. 38: 215-223.

1981. Coastal watermass replacement: its effect on zooplankton dynamics and the predator prey complex associated with larval capelin (Mallotus villosus). Can. J. Fish. Aquat. Sci. 39: 991-1003.
Godin, G. G. 1972. The analysis of tides. University of Toronto Press, Downsview, Ont. 264 p.

Hamner, W. M. L. P. Madin, A. L. Ailldredge, R. W. Gilmer, and P. P. HAMNER. 1975. Underwater observations of gelatinous zooplankton: sampling problems, feeding biology, and behaviour. Limnol. Oceanogr. 20: $907-917$.

HockING, R. R. 1978. The analysis and selection of variables in linear regression. Biometrics 32: 1-50.

JEAN, Y. 1964. Seasonal distribution of cod (Gadus morhua L.) along the Canadian Atlantic coast in relation to water temperature. J. Fish. Res. Board Can. 21: 429-460.

JefFers. G. W. 1931. Observations on the cod-fishery in the Strait of Belle Isle. Biol. Board Can. Bull. 18: 9 p.

Lear, W. H., J. W. Baird, J. C. Rice, J. E. Carscadden, G. R. Lil.Ly. and S. A. AKenhead. 1986. An examination of factors affecting the inshore cod fishery of Labrador and eastern Newfoundland. Can. Tech. Rep. Fish. Aquat. Sci. 1469: $71 \mathrm{p}$

LEE, A. J. 1952. The influence of hydrography on Bear Island cod fishery. Rapp. P.-V. Reun. Cons. Int. Explor. Mer 131: 73-102.

Leggett, W. C., K. T. Frank, and J. E. Carscadden. 1984. Meterological and hydrographic regulation of year-class strength in capelin Mallotus villosus. Can. J. Fish. Aquat. Sci. 41: 1193-1201

Lohmann, H. 1909. Die Gehäuse und Gallertblassen der Appendicularien und ihre Bedeutung für die Erforschung des Lebens im Meer. Verh. Dtsch. Zool. Ges. 19: 200-239.

Mahoney, E. M., and R. G. Buggeln. 1983. Seasonal variations in the concentrations of Oikopleura spp. (Tunicata: Appendicularia) in Conception Bay, Newfoundland. Can. Tech. Rep. Fish. Aquat. Sci. 1155: 12 p.

Martin, W. R. 1961. Canadian research report, 1960. B. Subarcas 4 and 5. Int Comm. Northw. Atl. Fish. Annu. Proc. 11: 31-37.

PAFFENHÖFER, G. -A. 1975. On the biology of Appendicularia of the southeastern North Sea. 10th Eur. Symp. Mar. Biol. 2: 437-455.

Rodriguez, M. O., AND A. L. Rojo. 1955. Report on the cruise by the Spanish trawler Mistral in the waters of Newfoundland, June-July, 1954. Int. Comm. Northw. Atl. Fish. Annu. Proc. 5: 51-57.

ScotT, J. S. 1982. Depth, temperature and salinity preferences of common fishes of the Scotian Shelf. J. Northw. Atl. Fish. Sci. 3: 29-39

Sokal, R. R., ANd R. J. Rohlf. 1969. Biometry. Freeman, San Francisco, CA. $776 \mathrm{p}$.

TAGgart, C. T. 1986. Mortality of larval capelin (Mallotus villosus Müller): environmental and density correlates during post-emergent dispersal. Ph.D thesis, McGill University, Montreal, Que. 209 p.

TagGart, C. T., And W. C. LegGetT. 1984. Efficiency of large-volume plankton pumps, and evaluation of a design suitable for deployment from small boats. Can. J. Fish. Aquat. Sci. 41: 1428-1435.

1987. Wind-forced hydrodynamics and their interaction with larval fish and plankton abundance: a time series analysis of physical-biological data. Can. J. Fish. Aquat. Sci. 44: 438-451.

Templeman, W. 1966. Marine resources of Newfoundland. Bull. Fish. Res. Board Can. 154: 170 p.

Templeman, W., and A. M. Fleming. 1956. The Bonavista longlining experiment, 1950-1953. Bull. Fish. Res. Board Can. 109: 55 p.

Templeman, W., AND A. W. MAY. 1965. Research vessel catches of cod in the Hamilton Inlet Bank area in relation to depth and temperature. Int. Comm. Northw. Atl. Fish. Spec. Publ. 6: 149-165.

Thompson, H. 1943. A biological and economic study of cod ( Gadus callarias L.) in the Newfoundland area. Res. Bull. (Fish.) Nfld. Dep. Nat. Resour. 14: $1-160$.

Trites, R. W., and K. F. Drinkwater. 1985. Overview of environmental conditions in the Northv est Atlantic during 1983. Northw. Atl. Fish. Org. Sci. Counc. Stud. 8: 7-20.

UDVARDY, M. D. F. 1954. Distribution of appendicularians in relation to the Strait of Belle Isle. J. Fish. Res. Board Can. 11: 431-453.

Van Guelpen, L., D. F. Markle, and D. J. DugGen. 1982. An evaluation of accuracy, precision and speed of several zooplankton subsampling techniques. J. Cons. Int. Explor. Mer 40: 226-236.

Woodhead, P. M. J., AND A. D. Woodhead. 1965. Seasonal changes in the physiology of the Barents Sea cod (Gadus morhua L.) in relation to its environment. Int. Comm. Northw. Atl. Fish. Spec. Publ, 6: 717-734.

WyatT, T. 1973. The biology of Oikopleura dioica and Fritillaria borealis in the Southern Bight. Mar. Biol. 22: 137-158

YAO, T. 1986. The response of currents in Trinity Bay, Newfoundland, to local wind forcing. Atmos. Ocean 24: 235-252. 